\title{
Egzogeninio prolino poveikis žaliosios šerytės (Setaria viridis L. Beauv.) atsparumui sausrai
}

\author{
Rimanta Vainoriené, \\ Natalija Burbulis, \\ Aušra Blinstrubienè, \\ Vaida Jonytienè \\ Aleksandro Stulginskio universitetas, \\ Studentug. 11, LT-53361 \\ Akademija, Kauno $r$. \\ El.paštas natalija.burbulis@asu.lt
}

\begin{abstract}
Tyrimai atlikti Aleksandro Stulginskio universiteto Jungtinių tyrimų centro (ASU JTC) Agrobiotechnologijos laboratorijoje. Tirtas egzogeninio prolino poveikis fotosintezės parametrų (maksimalus kvantų našumas, efektyvus kvantų našumas, nefotocheminis gesinimas ir fotocheminis gesinimas), tirpiụjų sacharidų ir endogeninio prolino pokyčiu dinamikai žaliosios šerytès augaluose sausros sąlygomis. Sausros sąlygos sudarytos augalams esant 13 fenologinëje fazèje (pagal BBCH skalę), juos auginant programuojamoje auginimo kameroje. Nustatyta, kad sausros sąlygos skatino endogeninio prolino ir tirpiujjų sacharidų kaupimąsi žaliosios šerytės augaluose, tačiau mažino maksimalų ir efektyvų kvantų našumus bei didino nefotocheminị ir fotocheminị gesinimą. Maksimalaus kvantų našumo ir endogeninio prolino kiekio padidèjimas bei fotocheminio gesinimo sumažějimas 15 ir $30 \mathrm{mM}$ dèl egzogeninio prolino koncentracijų poveikio didino žaliosios šerytės atsparumą sausrai. Purškimas per lapus $45 \mathrm{mM}$ egzogeninio prolino koncentracija inhibavo žaliosios šerytès fotosintezès sistemos veiklą sausros sąlygomis.
\end{abstract}

Raktažodžiai: fotosintezès parametrai, prolinas, tirpieji sacharidai, sausra, žalioji šerytė

\section{IVADAS}

Pastaraisiais metais ypač daug dèmesio skiriama klimato kaitos vertinimui ir kintančios aplinkos poveikio tyrimams. Tarpvyriausybinès klimato kaitos komisijos ataskaitoje teigiama, kad dèl klimato kaitos poveikio visuose žemynuose oro temperatūra pakilusi $0,85^{\circ} \mathrm{C}$ (IPCC, 2014). Ypač didelius iššūkius patiria žemès ūkis. Dèl gausẻjančių sausrų ir karščio protrūkių prognozuojamos ekonominès grèsmès (Christensen, Christensen, 2007; Dai, 2013; Trenberth et al., 2014). Europoje išskirtos svarbiausios su klimato kaita susietos rizikos (sausra, šaltis ir drègmès perteklius) reikšmingos ir Lietuvai (Stuogè ir kt., 2012).

Fotosintezès proceso šviesos fazè siejama su antrąja fotosistema (FSII), sudaryta iš reakcijos centro ir anteninio komplekso, kuriame šviesą sugeria chlorofilo ir karotinoidų molekulès. Sužadinta energija pernešama i̇ reakcijos centrą, kuriame vyksta vandens fotolize ir išlaisvinamas molekulinis deguonis. Tik 2-5 \% absorbuotos lapuose šviesos energijos panaudojama tiesiogiai fotosintezès procesui - fotocheminei energijai. Kita perteklinè sužadinta energija gali būti išsklaidyta kaip šiluma ir išspinduliuota chlorofilo fluorecencijos metu (Lambrev et al., 2012). Vandens deficito sąlygomis del difuzijos ir biocheminiu procesu sutrikimo inhibuojamas fotosintezès intensyvumas, sumažeja $\mathrm{CO}_{2}$ fiksavimas bei augalų augimas. Fotosintezès greitis sumažèja daugiausia dèl užsiverusių žiotelių, transpiracijos sulètėjimo, lapų temperatūros padidèjimo, ląstelès membranų pažaidų, fermentų, dalyvaujančių ATP sintezèje, veiklos sutrikimų (Mohammadkhani, Heidari, 2007; Flexas et al., 2008; Pinheiro, Chaves, 2011). 
Vienas iš būdų sušvelninti žalingą streso poveiki augalams - optimizuoti maisto medžiagu pasisavinimą purškiant augalus per lapus. Todèl nuolat ieškoma junginių, pasižyminčių antistresinėmis savybėmis, netoksiškų aplinkai ir žmogui. Aminorūgštys yra gyvybiškai būtinos baltymų sintezei, nulemiančios medžiagų apykaitą streso metu (Less, Galili, 2008). Aminorūgščių preparatai skatina fotosintezę, reguliuoja osmosinị slègi, žiotelių veiklą, dalyvauja metabolizme, skatina šaknų vystymąsi (Meijer, 2003). Purškiant augalus egzogeniniais preparatais aktyvios medžiagos greitai absorbuojamos ir tiesiogiai $\mathfrak{j j u n g i a m o s} \mathfrak{i}$ gyvybinius procesus. Papildomas tręšimas per lapus turi ittakos ir augalų mitybai per šaknis. Nustatytas teigiamas aminorūgščių komplekso poveikis žieminių kviečių ir vasarinių miežių fotosintezès sistemai sausros sąlygomis (Hammad, Ali, 2014; Mažuolytè-Miškinè ir kt., 2014).

Tyrimų tikslas - įvertinti egzogeninio prolino poveikį žaliosios šerytės atsparumui sausrai.

\section{TYRIMŲ METODAI IR SĄLYGOS}

Tyrimai atlikti ASU JTC Agrobiotechnologijos laboratorijoje. I $0,1 \times 0,12 \mathrm{~m}$ vegetacinius indus su substratu išsèta po 50 žaliosios šerytès sèklų. Augalai auginti programuojamoje auginimo kameroje esant $25 / 18{ }^{\circ} \mathrm{C}$ (dieną / naktị) temperatūrai, 16/8 val. (dieną / naktị) fotoperiodui ir $150 \mu \mathrm{mol} \mathrm{m} \mathrm{m}^{-2} \mathrm{~s}^{-1}$ apšviestumui. Sausros sąlygos (substrato drégnis 20-30\%) buvo sudarytos augalams esant 13 fenologineje fazeje (pagal $\mathrm{BBCH}$ skalę). Tiriamieji augalai nupurkšti 15, 30, $45 \mathrm{mM}$ koncentracijų prolino tirpalais. Kontrolinio varianto augalai nupurkšti distiliuotu vandeniu. Fotosintezès parametrai, prolino ir tirpiųjų sacharidų kiekiai nustatyti po 4, 8, 12 ir 16 sausros dienų. Stresinès sąlygos eliminuotos palaisčius augalus. Po 2 dienų, esant 65-70\% substrato drègniui, nustatyti fotosintezès parametrai, prolino ir tirpiujų sacharidų kiekiai.

Fotosintezès parametrai (maksimalus kvantu našumas, efektyvus kvantų našumas, nefotocheminis gesinimas ir fotocheminis gesinimas) nustatyti fluorimetru (IMAGING-PAM M-series, Walz, Germany). Prolino kiekis nustatytas taikant modifikuotą ninhydrino metodą (McClinchey, Kott, 2008). Bendrieji tirpieji sacharidai ivertinti antro- no metodu (Yemm, Willis, 1954). Matavimai atlikti spektrofotometru (Spectro UV-VIS Dual Beam Labomed, Inc, USA). Tyrimo duomenų statistinè analizè atlikta naudojantis kompiuterinemis programomis iš programų paketo SELEKCIJA (Tarakanovas, Raudonius, 2003).

\section{TYRIMŲ REZULTATAI IR JŲ APTARIMAS}

Sausros stresas gali inhibuoti fotosintezès elektronų transportą antroje fotosistemoje (FSII) (Chen, $\mathrm{Hsu}, 1995)$. Fotosintezès intensyvumui vertinti naudojamas chlorofilo a fluorescencijos metodas, kuris atspindi chlorofilų efektyvumą, elektronų pernašą FSII. Fotosintezès sistemos reakcija ị stresinių veiksnių poveiki vertinama pagal įvairius parametrus, pavyzdžiui, pagal efektyvaus kvantų našumo reikšmes (Baker, Rosenqvist, 2004). Efektyvus kvantų našumas labai jautrus rodiklis, tinkamai apibūdinantis augalo fotosintetinančios sistemos būklę. Manoma, kad efektyvaus kvantu našumo sumažejimas parodo FSII reakcijos centrų pažeidimą (Nar et al., 2009).

Mūsų tyrimais nustatyta, kad sausros stresas sumažino maksimalų ir efektyvų kvantų našumą II fotosistemoje žaliosios šerytės lapuose (1 pav.). Mažiausias maksimalus kvantu našumas nustatytas po 16 sausros dienų, tačiau, palyginti su 8 ir 12 sausros dienomis, skirtumai neesminiai ir statistiškai nepatikimi.

Efektyvus kvantų našumas statistiškai patikimai mažejo iki 12 sausros dienų ir buvo 1,75 karto mažesnis, palyginti su kontroliniais augalais. Tolesnis sausros trukmès ilginimas šiam parametrui esminès įtakos neturèjo. Sumažèjęs maksimalus ir efektyvus kvantų našumas parodè, kad sausra slopina FSII funkcijas. Manoma, kad tai vyksta dèl fotoinhibicijos FSII (Moustakas et al., 2011).

Palaisčius augalus maksimalus ir efektyvus kvantų našumai labai padidejo, tačiau buvo statistiškai patikimai 14,3 ir $10,12 \%$ mažesni, palyginti su sausra nepaveiktais augalais. Gauti rezultatai leidžia daryti prielaidą, kad žaliosios šerytès antroji fotosintezès sistema nepajegè visiškai atsistatyti po 16 sausros dienų.

Fotosintezès procesas vandens deficito sąlygomis ihibuojamas, kai dèl per didelio absorbuoto energijos srauto energija FS(II) sistemoje negali 


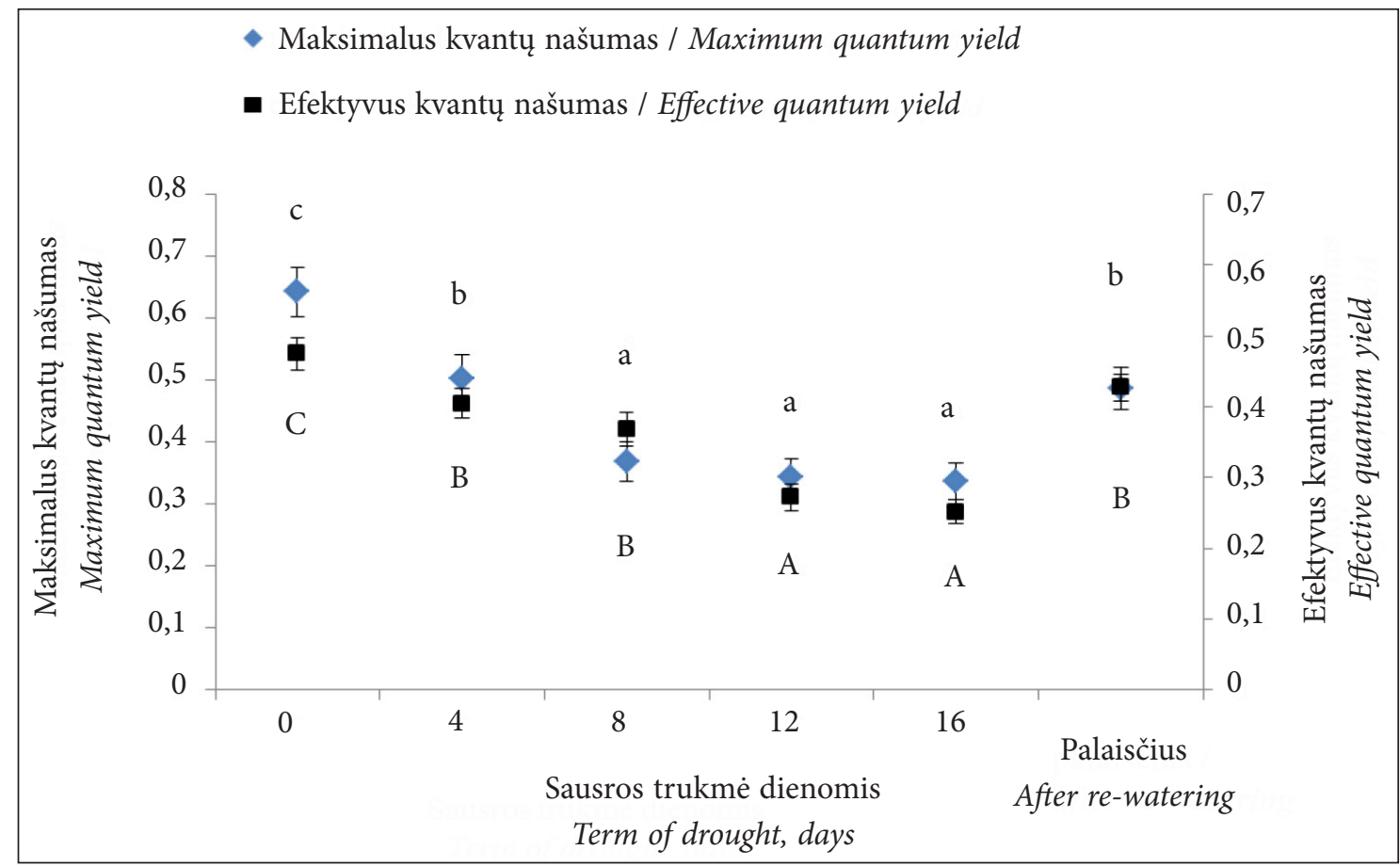

1 pav. Sausros poveikis maksimaliam ir efektyviam kvantų našumui žaliosios šerytės lapuose (tarp variantų vidurkių, pažymètų ne ta pačia raide (mažosiomis raidèmis - maksimalus kvantų našumas, didžiosiomis - efektyvus kvantų našumas), skirtumai yra esminiai $(P<0,05))$

Fig. 1. The effect of drought on the maximum and effective quantum yield in leaves of green foxtail (means not sharing a common letter (in lower case letters - maximum quantum yield, in capital letters - effective quantum yield) are significantly different $(P<0.05))$

išsisklaidyti ịprastu būdu. Tai sukelia perteklinę sužadinimo energiją ir pasireiškia fotoinhibicinis efektas (Biehler, Fock, 1996). Mokslininkai teigia, kad nefotocheminis gesinimas išsklaido perteklinę energiją ì šilumą palaikant fotosistemos veiklą ivvairių stresų sąlygomis (Efeoglu et al., 2009; Huang et al., 2013). Ilginant sausros trukmę nefotocheminis gesinimas žaliosios šerytės augaluose padidejo nuo 0,016 iki 0,05 , palyginti su sausra nepaveiktais augalais (2 pav.).

Tuo tarpu fotocheminis gesinimas žaliosios šerytès augaluose dèl sausros poveikio padidejo nuo 0,06 iki 0,17 , palyginti su augalais, augintais iprastomis drègmès sąlygomis. Didelè fotocheminio gesinimo reikšmè rodo, kad apsauginiai reguliacijos mechanizmai yra nepakankamai efektyvūs (Reddy et al., 2004). Palaisčius augalus nefotocheminis ir fotocheminis gesinimas statistiškai patikimai sumažèjo, palyginti su sausra paveiktais augalais, tačiau nepasiekè pradinio lygio.

Dèl biotinio ir abiotinio streso daugelis augalu kaupia aminorūgšti - proliną (Kavi Kishor et al., 2005; Kumar et al., 2010). Prolinas dalyvauja daugelyje ląstelių metabolizmo reakcijų: aktyvina kvèpavimą, reguliuoja deguonies asimiliaciją, yra $\mathrm{NH}_{2}$ grupès donoras aminorūgščių sintezèje. Augalui patekus ì nepalankias sąlygas prolinas vykdo ir apsauginę funkciją (Patton et al., 2007; Dörffling et al., 2009; Gothandam et al., 2010), kaip osmolitas padeda saugoti azoto ir anglies atsargas (Hare, Cress, 1997). Augalų fiziologinè būklè dažnai vertinama pagal endogeninio prolino kieki vegetatyviniuose organuose (Kishitani et al., 1994; Skuodienè, 1996). Sacharidai yra pirminès medžiagos, dalyvaujančios daugelyje augalo augimui ir vystymuisi reikalingų metabolizmo reakcijų (Loreti et al., 2001; Halford et al., 2010). Sacharidų kokybiniai ir kiekybiniai pokyčiai koreliuoja su streso tolerantiškumu, o jų kaupimasis priklauso nuo genotipo, augalo išsivystymo tarpsnio ir streso intensyvumo (Chaves et al., 2003; Halford et al., 2010). Nors sacharidų signalu perdavimo ir genų ekspresijos mechanizmai nèra visiškai ištirti, manoma, kad jie reguliuoja biosintezę ir organinių medžiagų kaupimąsi (Ho et al., 2001). 


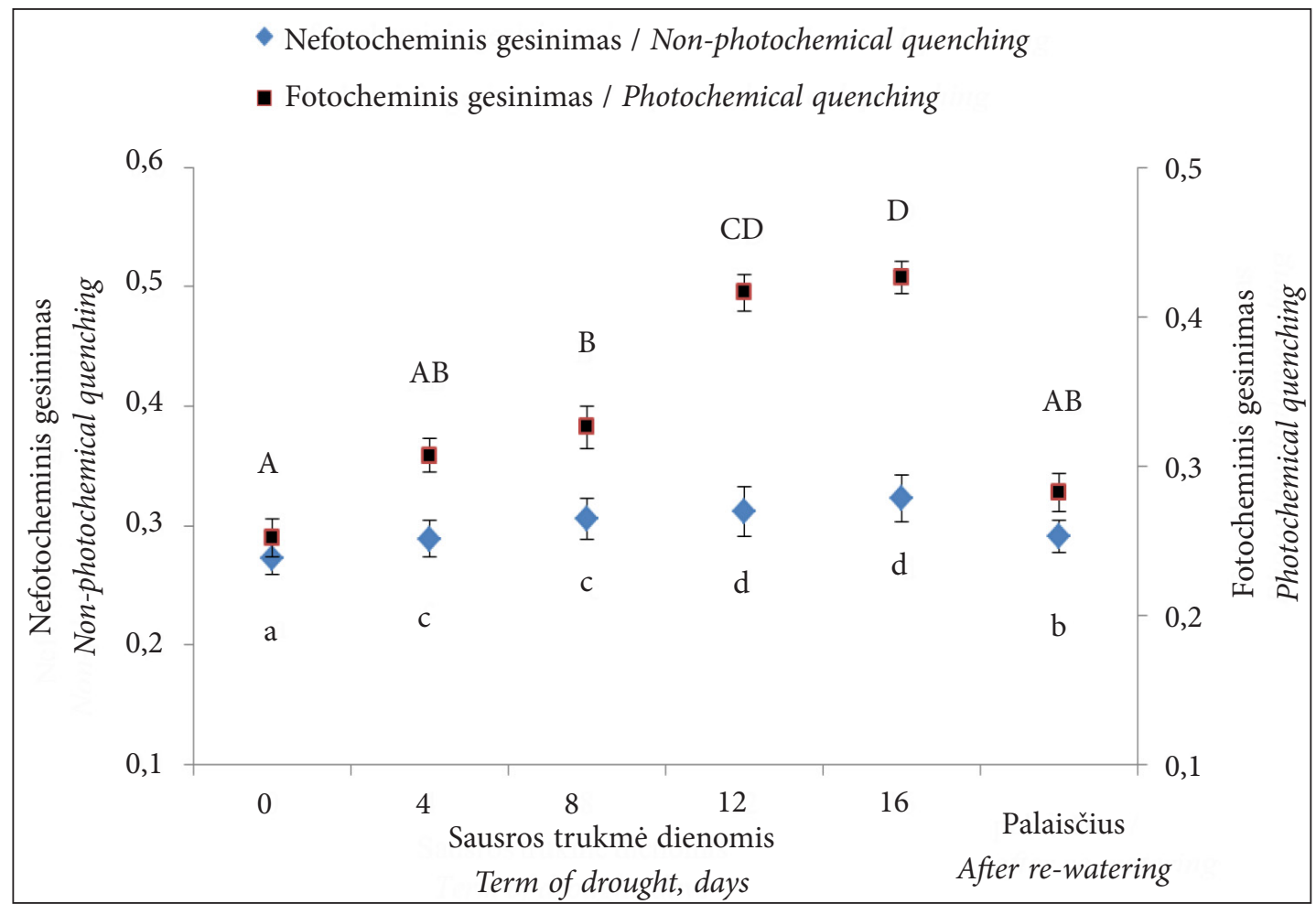

2 pav. Sausros poveikis nefotocheminiam ir fotocheminiam gesinimui žaliosios šerytės lapuose (tarp variantų vidurkių, pažymètų ne ta pačia raide (mažosiomis raidèmis - nefotocheminis gesinimas, didžiosiomis - fotocheminis gesinimas), skirtumai yra esminiai $(P<0,05))$

Fig. 2. The effect of drought on non-photochemical and photochemical quenching in leaves of green foxtail (means not sharing a common letter (in lower case letters - non-photochemical quenching, in capital letters - photochemical quenching) are significantly different $(P<0.05))$

Dèl sausros žaliosios šerytès augaluose statistiškai patikimai didejo prolino ir tirpiųjų sacharidų kiekiai (3 pav.). Po 16 sausros dienų augalų antžemineje dalyje prolino ir tirpiụjų sacharidų kiekiai padidejo atitinkamai $61,8 \mu \mathrm{M} \mathrm{g}^{-1}$ ir $107,7 \mathrm{mg} \mathrm{g}^{-1}$, palyginti su kontrole. Palaisčius augalus tirpiųjų sacharidų kiekis sumažejo iki pradinio lygio, o prolino kiekis liko statistiškai patikimai didesnis, palyginti su sausra nepaveiktais augalais.

Tyrimais nustatyta, kad egzogeninio prolino poveikis maksimaliam kvanto našumui žaliosios šerytės augaluose priklauso nuo panaudotos prolino koncentracijos (4 pav.).

Maksimalų kvantų našumą ịprastomis drègmès sąlygomis statistiškai patikimai didino $30 \mathrm{mM}$ prolino tirpalas, o statistiškai patikimai mažino - $45 \mathrm{mM}$ prolino tirpalas. Sausros sąlygomis maksimalus kvantų našumas esmingai didejo dèl 15 ir $30 \mathrm{mM}$ prolino poveikio, tačiau ženkliai mažèjo dèl $45 \mathrm{mM}$ prolino poveikio, palyginti su kontrole. Palaisčius augalus maksimalus kvantų našumas padidèjo visų variantų augaluose. Dèl 15 ir $30 \mathrm{mM}$ prolino poveikio maksimalus kvantu našumas buvo mažesnis, palyginti su sausra nepaveiktais augalais, tačiau šiek tiek didesnis, palyginti su trumpalaikiu (4 dienų) sausros poveikiu.

15 ir $30 \mathrm{mM}$ egzogeninio prolino koncentracijos statistiškai patikimai didino efektyvų kvantų našumą ịprastomis ir sausros sąlygomis (5 pav.). Efektyvaus kvantų našumo padidejjimas sausros sąlygomis rodo, kad optimali egzogeninio prolino koncentracija palaiko žaliosios šerytès fotosintezès sistemos stabilumą. Priešingai, $45 \mathrm{mM}$ prolino koncentracija ši fotosintezès parametrą statistiškai patikimai inhibavo. Palaisčius augalus efektyvus kvantų našumas buvo 0,022 (dèl $15 \mathrm{mM}$ prolino poveikio) ir 0,043 (dèl $30 \mathrm{mM}$ prolino poveikio) didesnis, palyginti su kontrolinio varianto (sausra nepaveiktais) augalais.

Nefotocheminis gesinimas žaliosios šerytès augaluose sausros metu kito priklausomai nuo egzogeninio prolino koncentracijos (6 pav.). Po 16 


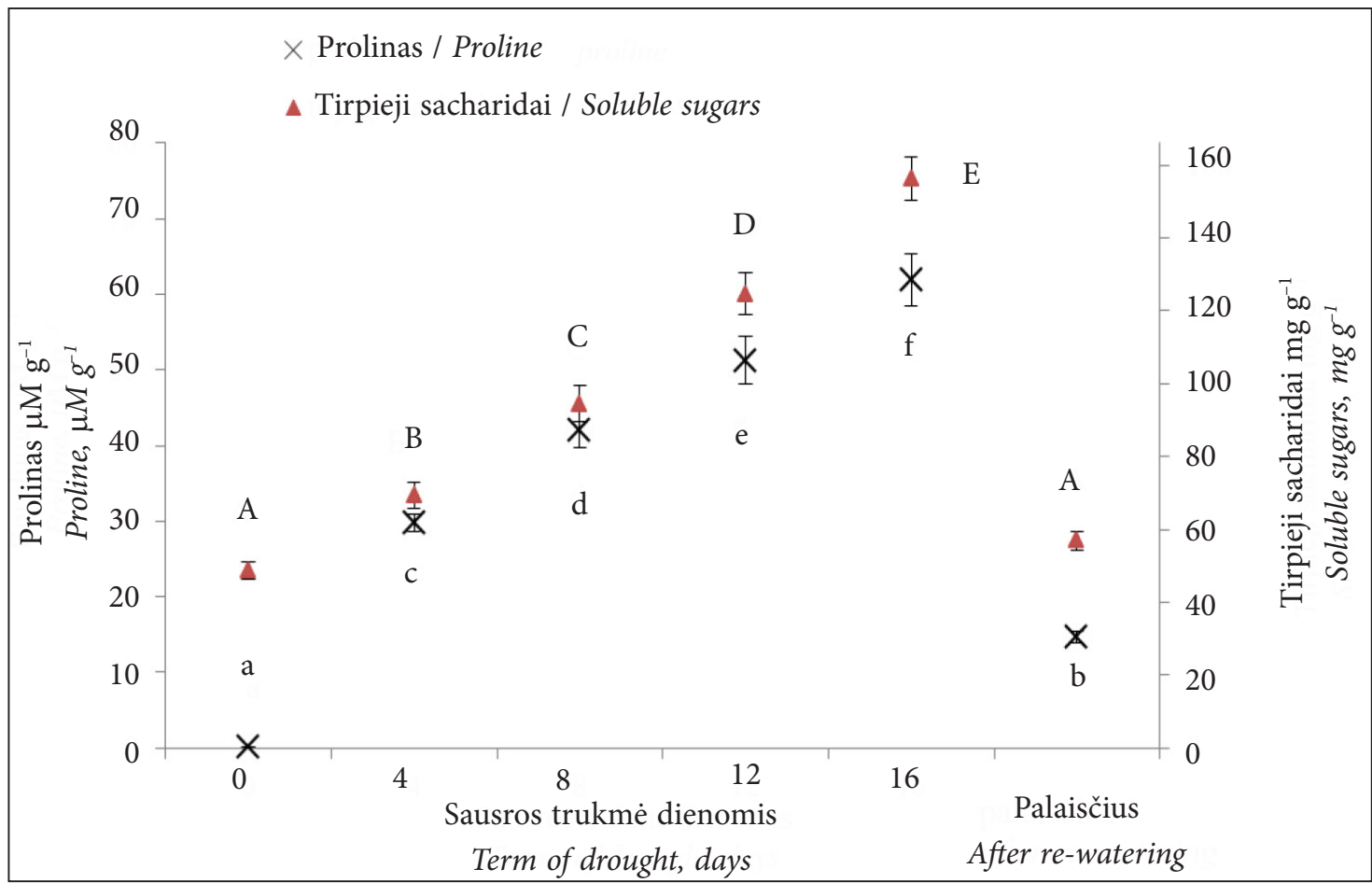

3 pav. Sausros poveikis prolino ir tirpiųjų sacharidų kiekiams žaliosios šerytės lapuose (tarp variantų vidurkių, pažymètų ne ta pačia raide (mažosiomis raidemis - prolinas, didžiosiomis - sacharidai), skirtumai yra esminiai $(P<0,05))$

Fig. 3. The effect of drought conditions on the content of proline and soluble sugars in leaves of green foxtail (means not sharing a common letter (in lower case letters - proline, in capital letters - soluble sugars) are significantly different $(P<0.05))$

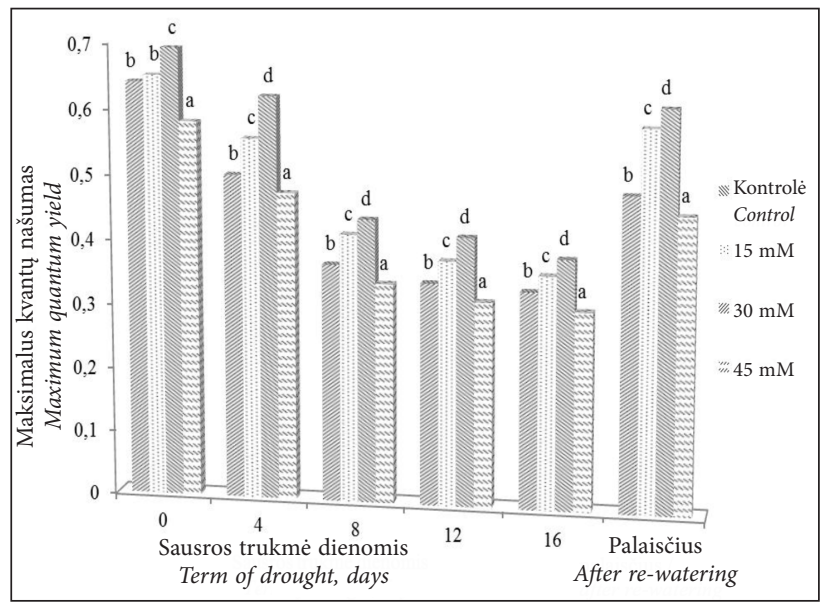

4 pav. Egzogeninio prolino poveikis maksimaliam kvantų našumui žaliosios šerytės lapuose sausros salygomis (tarp variantų vidurkių, pažymètų ne ta pačia raide $(\mathrm{a}, \mathrm{b})$, skirtumai yra esminiai $(P<0,05))$

Fig. 4. The effect of exogenous proline on the maximum quantum yield in leaves of green foxtail under drought conditions (means not sharing a common letter $(a, b)$ are significantly different $(P<0.05))$

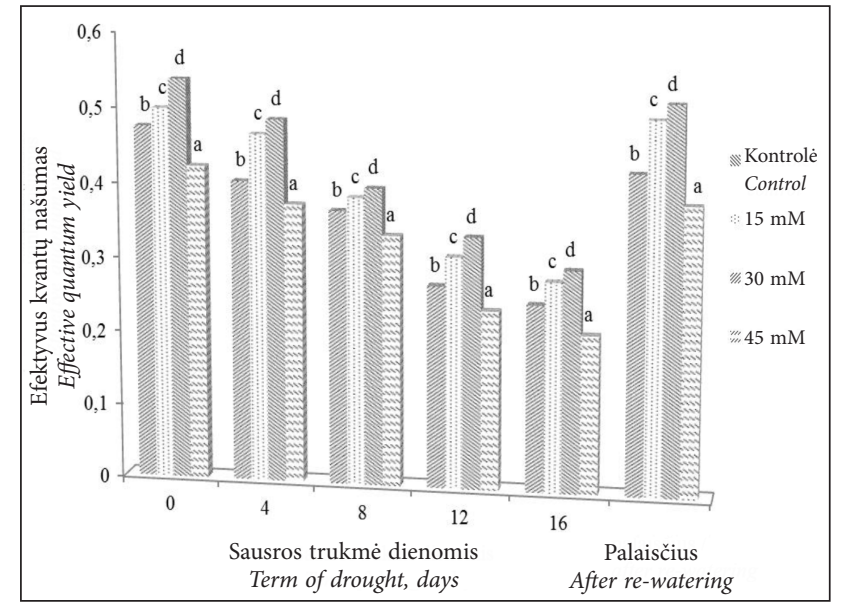

5 pav. Egzogeninio prolino poveikis efektyviam kvantų našumui žaliosios šerytės lapuose sausros salygomis (tarp variantų vidurkių, pažymètų ne ta pačia raide (a, b), skirtumai yra esminiai $(P<0,05))$

Fig. 5. The effect of exogenous proline on the efective quantum yield in leaves of green foxtail under drought conditions (means not sharing a common letter $(a, b)$ are significantly different $(P<0.05))$ 
sausros dienų nefotocheminis gesinimas statistiškai patikimai padidejo dèl 30 ir $45 \mathrm{mM}$ prolino poveikio. Palaisčius augalus po sausros nustatytas ženklus nefotocheminio gesinimo sumažejimas visų variantų augaluose. Tirtosios prolino koncentracijos skatino intensyvesnį nefotocheminio gesinimo mažèjimą eliminavus sausros stresą.

Fotocheminis gesinimas žaliosios šerytès lapuose sausros metu mažèjo dèl 15 ir $30 \mathrm{mM}$ prolino poveikio, tačiau statistiškai patikimai didejo dèl $45 \mathrm{mM}$ prolino poveikio (7 pav.). Fotocheminio gesinimo sumažejimas dèl egzogeninio prolino poveikio leidžia daryti prielaidą, kad 15 ir $30 \mathrm{mM}$ prolino koncentracijos palaiko augalų apsauginių mechanizmų efektyvumą sausros sąlygomis. Analogiškas teigiamas egzogeninio prolino poveikis nustatytas taip pat ir kukurūzų atsparumui sausrai (Ali et al., 2007). Palaisčius žaliosios šerytès augalus po sausros nustatytas ženklus fotocheminio gesinimo sumažèjimas dèl 15 ir $30 \mathrm{mM}$ egzogeninio prolino poveikio, tačiau didesnè $(45 \mathrm{mM})$ prolino koncentracija ši fotosintezès parametrą statistiškai patikimai didino, palyginti su kontrolinio varianto augalais.

Tirtosios egzogeninio prolino koncentracijos statistiškai patikimai didino endogeninio prolino kiekị žaliosios šerytès lapuose (8 pav.). Didinant egzogeninio prolino koncentraciją endogeninio prolino kiekis nuosekliai didejo sausros metu.

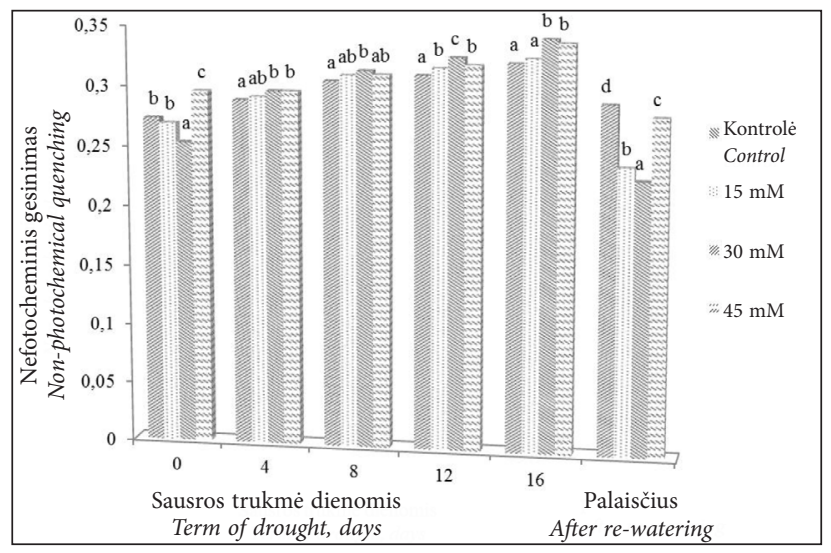

6 pav. Egzogeninio prolino poveikis nefotocheminiam gesinimui žaliosios šerytès lapuose sausros sąlygomis (tarp variantų vidurkių, pažymètų ne ta pačia raide (a, b), skirtumai yra esminiai $(P<0,05))$

Fig. 6. The effect of exogenous proline on the non-photochemical quenching in leaves of green foxtail under drought conditions (means not sharing a common letter $(a, b)$ are significantly different $(P<0.05))$
Po 16 sausros dienų endogeninio prolino kiekis dèl egzogeninio prolino poveikio padidèjo 1,11,4 karto, palyginti su kontrole. Palaisčius augalus po sausros mažiausias endogeninio prolino kiekis nustatytas augaluose, purkštuose $15 \mathrm{mM}$ prolino tirpalu. Greitas endogeninio prolino sumažèjimas pašalinus stresoriaus poveikị - vienas pagrindinių veiksnių, lemiančių augimo atsinaujinimą ir atsparumą stresams (Verslues, Sharma, 2010).

Tirpiųjų sacharidų kiekis varijavo priklausomai nuo prolino koncentracijos (9 pav.).

Po 12 sausros dienų tirpiųjų sacharidų kaupimąsi statistiškai patikimai didino 15 ir $30 \mathrm{mM}$ prolino koncentracijos, tačiau po 16 sausros dienų šios egzogeninio prolino koncentracijos tirpiųjų sacharidų kiekiui žaliosios šerytės lapuose esminès ịtakos neturejjo. Po sausros palaisčius augalus nustatyta, kad dèl 15 ir $30 \mathrm{mM}$ prolino koncentracijos poveikio augalai sukaupe atitinkamai 1,1 ir 1,3 karto mažiau tirpiųjų sacharidų, palyginti su kontroliniu variantu. Egzogeninis prolinas skatino endogeninio prolino ir tirpiųju sacharidų kaupimąsi baltažiedžio vairenio augaluose sausros sąlygomis ir dèl šių junginių sąveikos padidejo augalu atsparumas sausrai (Moustakas et al., 2011). Endogeninio prolino - tirpiųu sacharidų sąveika atlieka svarbią funkciją antioksidaciniuose procesuose, apsaugodama FSII sistemą nuo pažaidų.

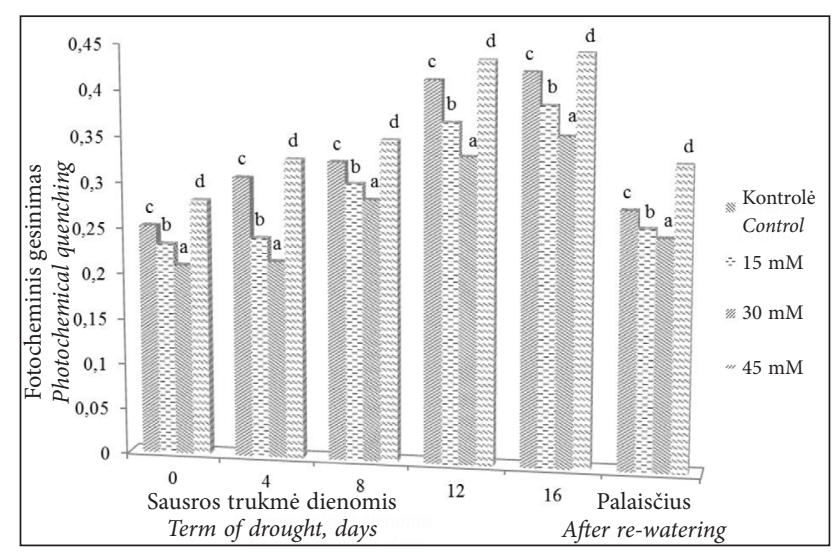

7 pav. Egzogeninio prolino poveikis fotocheminiam gesinimui žaliosios šerytės lapuose sausros sąlygomis (tarp variantų vidurkių, pažymètų ne ta pačia raide ( $a$, b), skirtumai yra esminiai $(P<0,05))$

Fig. 7. The effect of exogenous proline on the photochemical quenching in leaves of green foxtail under drought conditions (means not sharing a common letter $(a, b)$ are significantly different $(P<0.05))$ 


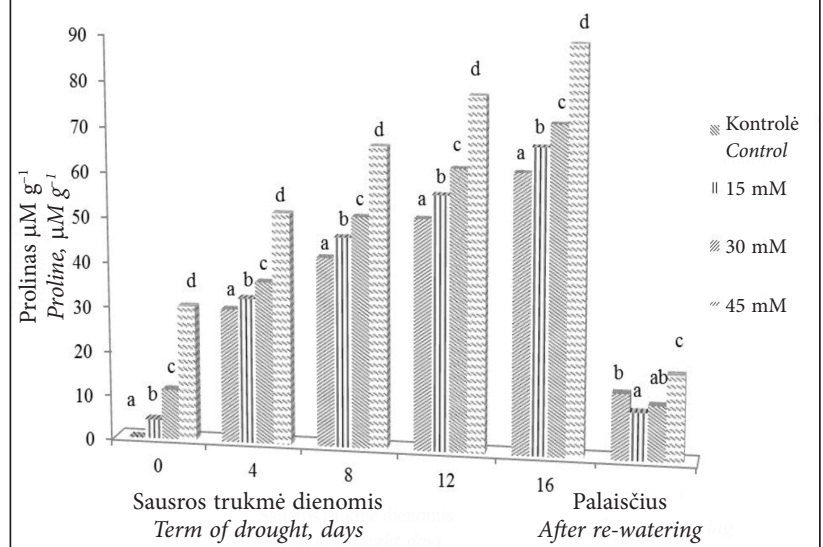

8 pav. Egzogeninio prolino poveikis endogeninio prolino kiekiui žaliosios šerytès lapuose sausros sąlygomis (tarp variantų vidurkių, pažymètų ne ta pačia raide $(\mathrm{a}, \mathrm{b})$, skirtumai yra esminiai $(P<0,05))$

Fig. 8. The effect of exogenous proline on the content of endogenous proline in leaves of green foxtail under drought conditions (means not sharing a common letter $(a, b)$ are significantly different $(P<0.05))$

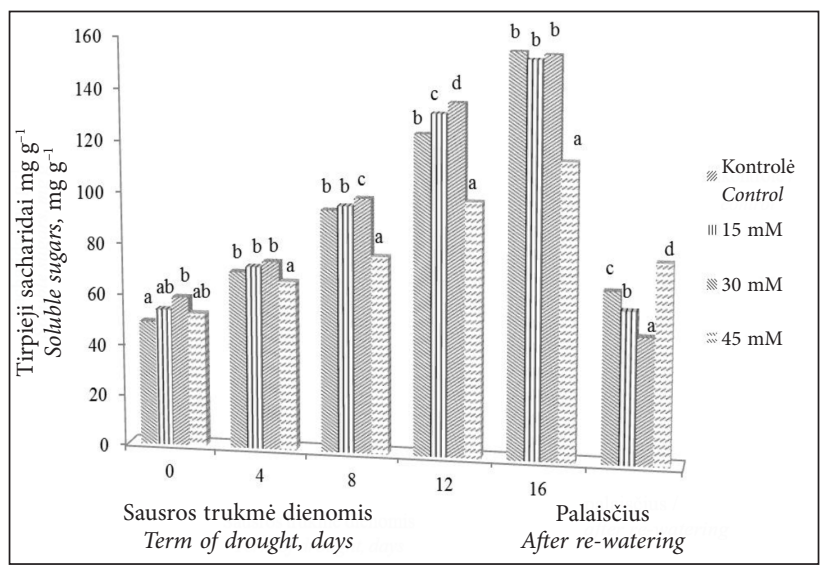

9 pav. Egzogeninio prolino poveikis tirpiųju sacharidų kiekiui žaliosios šerytès lapuose sausros sąlygomis (tarp variantų vidurkių, pažymètų ne ta pačia raide $(\mathrm{a}, \mathrm{b})$, skirtumai yra esminiai $(P<0,05))$

Fig. 9. The effect of exogenous proline on the content of soluble sugars in leaves of green foxtail under drought conditions (means not sharing a common letter $(a, b)$ are significantly different $(P<0.05))$

Priešingai, $45 \mathrm{mM}$ egzogeninio prolino koncentracija tirpiujų sacharidų kieki sausros metu statistiškai patikimai mažino, o po sausros atlaisčius augalus - didino, todèl augalai sukaupé 1,2 karto daugiau tirpiųuc sacharidų, palyginti su kontrole. Neigiamas didesnių egzogeninio prolino koncentraciju poveikis taip pat nustatytas tyrimuose su baltažiedžiais vaireniais ir pomidorais (Hare et al., 2001; Heuer, 2003).

\section{IŠVADOS}

1. Sausros sąlygos skatino endogeninio prolino ir tirpiųjų sacharidų kaupimąsi žaliosios šerytės augaluose, tačiau mažino maksimalų ir efektyvų kvantų našumus, didino nefotocheminị ir fotocheminị gesinimą.

2. Maksimalaus kvantų našumo ir endogeninio prolino kiekio padidejimas bei fotocheminio gesinimo sumažéjimas 15 ir $30 \mathrm{mM}$ dèl egzogeninio prolino koncentracijų poveikio didino žaliosios šerytès atsparumą sausrai.

3. Purškimas per lapus $45 \mathrm{mM}$ egzogeninio prolino koncentracija inhibavo žaliosios šerytès fotosintezės sistemos veiklą sausros sąlygomis.

Gauta 20160831

Priimta 20160919

\section{LITERATŪRA}

1. Ali Q., Ashraf M., Athar H. U. R. 2007. Exogenously applied proline at different stages enhanced growth of two maize cultivars grown under water deficit conditions. Pakistan Journal of Botany. Vol. 39. P. 1133-1144.

2. Baker N. R., Rosenqvist E. 2004. Application of chlorophyll fluorescence can improve crop production strategies: an examination of future possibilities. Journal of Experimental Botany. Vol. 55. P. 1607-1621.

3. Biehler K., Fock H. 1996. Evidence for the contribution of the mehler-peroxidase reaction in dissipating excess electrons in drought-stressed wheat. Plant Physiology. Vol. 112. No. 1. P. 265-272.

4. Chaves M. M., Maroco J. P., Pereira J. S. 2003. Understanding plant responses to drought from genes to the whole plant. Functional Plant Biology. Vol. 30. P. 239-264.

5. Chen Y. H., Hsu B. D. 1995. Effects of dehydration on the electron transport of Chlorella. An in vivo fluorescence study. Photosynthesis Research. Vol. 46. No. 1-2. P. 295-299.

6. Christensen J. H., Christensen O. B. 2007. A summary of the prudence model projections of changes in European climate by the end of this century. Climatic Change. Vol. 81. No. 1. P. 7-30.

7. Dai A. 2013. Increasing drought under global warming in observations and models. Nature Climate Change. Vol. 3. No. 1. P. 52-58. 
8. Dörffling K., Dörffling H., Luck E. 2009. Improved frost tolerance and winter hardiness in proline over accumulating winter wheat mutants obtained by in vitro-selection is associated with increased carbohydrate, soluble protein and abscisic (ABA) levels. Euphytica. Vol. 165. P. 545-556.

9. Efeoglu B., Ekmekci Y., Cicek N. 2009. Physiological responses of three maize cultivars to drought stress and recovery. South African Journal of Botany. Vol. 75. P. 34-42.

10. Flexas J., Ribas-Carbó M., Diaz-Espejo A., Galmés J., Medrano H. 2008. Mesophyll conductance to $\mathrm{CO}_{2}$ : current knowledge and future prospects. Plant, Cell \& Environment. Vol. 31. No. 5. P. 602-621.

11. Gothandam K. M., Nalini E., Karthikeyan S., Shin J. S. 2010. OsPRP3, a flower specific proline-rich protein of rice, determines extracellular matrix structure of floral organs and its overexpression confers cold-tolerance. Plant Molecular Biology. Vol. 72. P. 125-135.

12. Halford N. G., Curtis T. Y., Muttucumaru N., Postiles J., Motoram D. S. 2010. Sugar in crop plants. Annals of Applied Biology. Vol. 158. P. 1-25.

13. Hammad S. A. R., Ali O. A. M. 2014. Physiological and biochemical studies on drought tolerance of wheat plants by application of amino acids and yeast extract. Annals of Agricultural Sciences. Vol. 59. No. 1. P. 133-145.

14. Hare P. D., Cress W. A. 1997. Metabolic implications of stress-induced proline accumulation in plants. Plant Growth Regulators. Vol. 21. P. 79-102.

15. Hare P. D., Cress W. A., van Staden J. 2001. The effect of exogenous proline and proline analogues on in vitro shoot organogenesis in Arabidopsis. Plant Growth Regulation. Vol. 34. P. 203-207.

16. Heuer B. 2003. Influence of exogenous application of proline and glycinebetaine on growth of salt-stressed tomato plants. Plant Science. Vol. 165. P. 693-699.

17. Ho S. L., Chao Y. C., Tong W. F., Yu S. M. 2001. Sugar coordinately and differentially regulates growth- and stress-related gene expression via a complex signal transduction network and multiple control mechanisms. Plant Physiology. Vol. 125. P. 877-890.

18. Huang C., Zhao S., Wang L., Anjum S. A., Chen M., Zhou H., Zou C. 2013. Alteration in chlorophyll fluorescence, lipid peroxidation and antioxidant enzymes activities in hybrid ramie (Boehmeria nivea L.) under drought stress. Australian Journal of Crop Science. Vol. 7. P. 594-599.
19. IPCC. 2014. Summary for Policymakers. In: Climate Change 2014: Impacts, Adaptation, and Vulnerability. Part A: Global and Sectoral Aspects. Contribution of Working Group II to the Fifth Assessment Report of the Intergovernmental Panel on Climate Change. Eds. C. B. Field, V. R. Barros, D. J. Dokken, K. J. Mach, M. D. Mastrandrea, T. E. Bilir, M. Chatterjee, K. L. Ebi, Y. O. Estrada, R. C. Genova, B. Girma, E. S. Kissel, A. N. Levy, S. MacCracken, P. R. Mastrandrea, L. L. White. Cambridge, United Kingdom: Cambridge University Press. P. 1-32.

20. Kavi Kishor P. B., Sangam S., Amrutha R. N., Laxmi P. S., Naidu K. R., Rao K. R., Rao S., Reddy K. J., Theriappan P., Sreenivasulu N. 2005. Regulation of proline biosynthesis, degradation, uptake and transport in higher plants: its implications in plant growth and abiotic stress tolerance. Current Science. Vol. 88. P. 424-438.

21. Kishitani S., Watanabe K., Yasuda S., Arakawa K., Pakabe T. 1994. Accumulation of glycinebetaine during cold acclimation and freezing tolerance in leaves of winter and spring barley plants. Plant, Cell \& Environment. Vol. 17. P. 89-95.

22. Kumar V., Shriram V., Kavi Kishor P. B., Jawali N., Shitole M. G. 2010. Enhanced proline accumulation and salt stress tolerance of transgenic indica rice by over-expressing P5CSF129A gene. Plant Biotechnology Reports. Vol. 4. P. 37-48.

23. Lambrev P. H., Miloslavina Y., Jahns P., Holzwarth A. R. 2012. On the relationship between non-photochemical quenching and photoprotection of photosystem II. Biochimica et Biophysica Acta. Vol. 1817. P. 760-769.

24. Less H., Galili G. 2008. Principal transcriptional programs regulating plant amino acid metabolism in response to abiotic stresses. Plant Physiology. Vol. 147. No. 1. P. 316-330.

25. Loreti E., de Bellis L., Alpi A., Perata P. 2001. Why and how do plant cells sense sugars? Annals Botany. Vol. 88. P. 803-812.

26. Mažuolytė-Miškinė E., Pranckietienė I., Dromantienè R., Pranckietis V. 2014. Aminorūgščių poveikis fotosintezès pigmentams vasarinių miežių lapuose imitacinès sausros sąlygomis. Žemès ūkio mokslai. T. 20. Nr. 4. P. 253-265.

27. McClinchey S. L., Kott L. S. 2008. Production of mutants with high cold tolerance in spring canola (Brassica napus). Euphytica. Vol. 162. P. 18-27.

28. Meijer A. J. 2003. Amino acids as regulators and components of nonproteinogenic pathways. The Journal of Nutrition. Vol. 133. P. 2057-2062. 
29. Mohammadkhani N., Heidari R. 2007. Effects of water stress on respiration, photosynthetic pigments and water content in two maize cultivars. Pakistan Journal of Biological Sciences. Vol. 10. No. 22. P. 4022-4028.

30. Moustakas M., Sperdouli I., Kouna T., Antonopoulou C. I., Therios I. 2011. Exogenous proline induces soluble sugar accumulation and alleviates drought stress effects on photosystem II functioning of Arabidopsis thaliana leaves. Plant Growth Regulation. Vol. 65. No. 2. P. 315.

31. Nar H., Saglam A., Terzi R., Várkonyi Z., Kadioglu A. 2009. Leaf rolling and photosystem II efficiency in Ctenanthe setosa exposed to drought stress. Photosynthetica. Vol. 47. P. 429-436.

32. Patton A. J., Cunningham S. M., Volenec J. J., Reicher Z. J. 2007. Differences in freeze tolerance of zoysiagrasses. II. Carbohydrates and proline. Crop Science. Vol. 47. P. 2170-2181.

33. Pinheiro C., Chaves M. M. 2011. Photosynthesis and drought: can we make metabolic connections from available data? Journal of Experimental Botany. Vol. 62. No. 3. P. 869-882.

34. Reddy A. R., Chaitanya K. V., Vivekanandan M. 2004. Drought-induced responses of photosynthesis and antioxidant metabolism in higher plants. Journal of Plant Physiology. Vol. 161. P. 1189-1202.

35. Skuodienè L. 1996. Medžių būklès vertinimas prolino analizès metodu. Ekologija. Nr. 8. P. 55-63.

36. Stuogè I., Ribikauskas V., Lazauskas S., Radzevičius G. 2012. Klimato kaitos ittaka Lietuvos žemès ūkiui: iššūkiai, situacijos analizè ir prognozès. Kaimo raidos kryptys žinių visuomeneje. T. 2. Nr. 4. P. 43-55.

37. Tarakanovas P., Raudonius S. 2003. Agronominiu tyrimu duomenu statistine analize taikant kompiuterines programas ANOVA, STAT, SPLIT-PLOT iš paketo "Selekcija“ ir „Irristat". Akademija, Kèdainių r. 57 p.

38. Trenberth K. E., Dai A., van der Schrier G., Jones P. D., Barichivich J., Briffa K. R., Sheffield J. 2014. Global warming and changes in drought. Nature Climate Change. Vol. 4. P. 17-22.

39. Verslues P. E., Sharma S. 2010. Proline metabolism and its implication for plant-environment interaction. The Arabidopsis Book. Vol. 8. P. 1-23.

40. Yemm E. W., Willis A. J. 1954. Estimation of carbohydrates in plant extracts by anthore. Biochemistry. Vol. 57. P. 508-514.

\section{Rimanta Vainorienė, Natalija Burbulis, Aušra Blinstrubienè, Vaida Jonytienė}

\section{THE EFFECT OF EXOGENOUS PROLINE ON RE- SISTANCE OF GREEN FOXTAIL (SETARIA VIR- IDIS L. BEAUV.) TO DROUGHT STRESS}

\section{Summary}

The study was carried out at the ASU JRC Laboratory of Agrobiotechnology. The effect of exogenous proline on photosynthetic parameters (maximum quantum yield, effective quantum yield, non-photochemical quenching, and photochemical quenching), soluble sugars and proline content in green foxtail under drought stress was evaluated. It was found that drought conditions induced accumulation of endogenous proline and soluble sugars in green foxtail plants, but reduced the maximum and effective quantum yield as well as increased non-photochemical and photochemical quenching. Increasing in the maximum quantum yield and the endogenous proline content and decreasing in the photochemical quenching under the influence of 15 and $30 \mathrm{mM}$ exogenous proline resulted in increasing of the green foxtail resistance to drought. Spraying with $45 \mathrm{mM}$ concentration of exogenous proline inhibited green foxtail photosynthetic systems under drought conditions.

Keywords: photosynthetic parameters, proline, soluble sugars, drought, green foxtail 